\title{
Technology Adoption Readiness in Disadvantaged Universities during COVID-19 Pandemic in South Africa
}

\author{
Kehinde Aruleba ${ }^{1}$, Nobert Jere ${ }^{1} \&$ Obert Matarirano ${ }^{2}$ \\ ${ }^{1}$ Department of Information Technology, Walter Sisulu University, East London, South Africa \\ ${ }^{2}$ Department of Accounting and Finance, Walter Sisulu University, South Africa \\ Correspondence: Kehinde Aruleba, Department of Information Technology, Walter Sisulu University, East London, \\ South Africa.
}

Received: August 30, 2021

Accepted: January 19, 2022

Online Published: January 24, 2022

doi:10.5430/ijhe.v11n2p172

URL: https://doi.org/10.5430/ijhe.v11n2p172

\begin{abstract}
The Covid-19 pandemic has affected hundreds of million lives and taken over four million lives to date. As a result, governments and policymakers see the need for emergency action to reduce the spread of the virus. In an attempt to contain the virus, governments and policymakers worldwide introduced a different range of protection measures and interventions to change their citizen's behaviours, primarily through social distancing, interprovince lockdown, stay at home strategies, and quarantines. The different lockdown measures have created unique and challenging conditions with no documented equivalent in the education sector. A significant effect was that many Higher Education institutions worldwide were not ready to switch to online teaching and learning when the governments announced the sudden lockdown. This study discusses the effects of the Covid-19 pandemic on South Africa Higher Education Institutions, focusing on the historically disadvantaged universities. The study went further to evaluate the readiness of lecturers from selected disadvantaged universities to adopting online teaching and learning by applying the Technology Readiness-Acceptance Model (TRAM). Quantitative data was collected through an online questionnaire. Results show that the higher the average of optimism and innovativeness among the respondents' point towards the readiness of adopting technology. On the other hand, higher the average insecurity and discomfort show the uneasiness of adopting technologies by the respondents.
\end{abstract}

Keywords: Covid-19, technology readiness, online teaching and learning, technology adoption

\section{Introduction}

Information technology and the internet has tremendously impacted the education industry across the world. They have unquestionably contributed to developing flexible educational opportunities that allow a diverse range of students to learn remotely. This form of education, sometimes referred to as distance learning, often uses the internet and other digital tools for online teaching and learning. Online learning is a subcategory of distance education (Bates, 2005). Online education has been used for almost two decades in universities (Barnard, 1997; Graham, 2019). Over time, different online educational platforms and technologies have been developed, evaluated, and they have significantly proven to be efficient in performing the task they were developed for. Higher education, especially disadvantaged universities, has been slow in adopting this form of education despite the platforms' efficiency. A significant reason for this is that most lecturers and students are used to and have mastered the face-to-face learning approach (Howard et al., 2021). For example, Pulham \& Graham (2018) stated that online learning is hardly used aside from distance learning. However, when they are to be used, they are usually introduced as a form of blended learning, where a specific aspect of the learning is done online and in the student's control. For the context of this paper, disadvantaged universities in South Africa are a cluster of higher education institutions (HEI) created under apartheid to cater for Africans and other non-white populations.

However, with the recent COVID-19 pandemic, online learning has gained a lot of popularity and attention from universities around the globe. The Covid-19 pandemic has affected hundreds of million lives and taken over four million lives to date. As a result, governments and policymakers see the need for emergency action to reduce the spread of the virus. In an attempt to contain the virus, governments and policymakers worldwide introduced a different range of protection measures and interventions to change their citizens' behaviours, primarily through social distancing, interprovince lockdown, stay at home strategies, and quarantines. These measures were to flatten the 
curve and also reduce the burden on the public health system. This paper focuses on the readiness of the previously disadvantaged universities lecturers in South Africa to adopt online teaching and learning during the COVID-19 pandemic.

In March 2020, the government of South Africa announced a level 5 lockdown due to the pandemic, which included the closure of schools across the country (Siedner et al., 2020). Before the announcement, many universities were already in shock and confused about handling and managing their lectures, classrooms, and student residents. Some schools had to cancel classes at the last minute to avoid students mass gatherings. Many students were left with only the option of travelling back to their home countries and home all over South Africa due to the closure of student's accommodation and the level 5 lockdown rules. In an attempt to salvage the academic year, few schools across the country introduced crash courses for their lecturers on online teaching methods and platforms such as Blackboard, Zoom, Google classroom, Moodle and other online learning platforms. By the end of March 2020, public universities executives met and agreed to switch entirely to online learning by 20 April 2020. Sharon (2020) reported that about ten universities indicated their immediate interest in going entirely online. However, for previously disadvantaged universities, it was challenging to implement such a decision immediately. It is worth noting that from the ten universities, the University of Western Cape is the only historically disadvantaged university that indicates its immediate interest. This paper discusses some of the reasons these universities found it challenging to implement online teaching immediately.

The rest of this paper is organised as follow Section 2 discusses online education versus face-to-face; online education during the COVID-19 pandemic is discussed in Section 3. Section 4 presents the methodology of this study. Section 5 shows the paper discussion and findings, and Section 6 shows the conclusion of the paper.

\section{Online Education versus Face-to-Face}

According to Baran et al. (2013), the online education approach differs from the traditional face-to-face learning approach; hence, its pedagogies must be developed. Over the last decades, there has been a rapid growth in the adoption of distance and online education using digital technology and media in teaching. For example, in South Africa, the University of South Africa (UNISA), a distance education university, currently has over 400,000 students enrolled, making it the largest university in South Africa and on the African continent. The increasing number of students enrolling in universities such as UNISA shows a significant possible shift in education. Therefore, it is essential to do in-depth research of the various teaching pedagogy and introduce contents and policies to inform efforts to improve its adoption by universities staffs and students. These will help educate them, especially the previously disadvantaged lecturers, on the myths about online learning.

According to the post-test design findings in Sussman \& Dutter (2010), students' performance regarding their medium of instruction (i.e., whether fully online or face-to-face) were the same for both mediums. The result of the findings was obtained from the analysis of the same course for four years. However, other studies found significant practical and statistical differences in student performance based on the mode and medium their courses were delivered (Jaggars \& Bailey, 2010; Lim et al., 2007; Muilenburg \& Berge, 2005). A positive difference was noticed in Hijazi (2003), suggesting that students tend to achieve more in distance learning than face-to-face. However, there were no significant differences in students' attitudes towards their courses irrespective of teaching mode. In another study, Navarro \& Shoemaker (2000) examined several undergraduate learners enrolled on an introductory economics course. The study compared the perception and performance of traditional learners to that of cyber learners. The comparison indicated that cyber learners learn the same way or even better with more satisfaction than traditional learners regardless of academic aptitude, gender, computer skills and race.

The importance of adopting online teaching and learning cannot be overemphasised, especially with the recent COVID-19 outbreak worldwide. Therefore, learners and educators need to accept this new norm of teaching and learning; more importantly, disadvantaged universities and students must embrace these not to be left behind in this digital era. There are numerous advantages of online learning. For instance, Ebner \& Gegenfurtner (2019) highlighted the importance of video-conferencing technologies in webinars. These technologies allow real-time interaction between lecturers or instructors and students or participants without the lecturer being physically present in the student location. The synchronous setup of the technologies allows students or participants to directly communicate with their lecturers, who can give instant feedback (Gegenfurther, 2020). These technologies are also modelled to allow students to collaborate and work in groups (Joshi et al., 2013).

\section{Online Education during COVID-19}

The current pandemic prompts the change in the usual teaching methods in ways that make online education quickly 
transition from a supplementary method to a key method. This rapid transition brought obvious challenges and difficulties to higher education, such as introducing new requirements and platforms for teaching and learning, the satisfaction of these new requirements, training of lecturers and students, and affordability of the necessary technologies to excel in this new education method. These platforms and technologies provide a strong help and support for education during the pandemic period and bring a new experience for users; however, it also brings several controversies and challenges mainly faced by disadvantaged users.

The findings in Omodan (2020) stated some of the critical problems disadvantaged universities in South Africa encounter in transiting swiftly to online education at the beginning of the pandemic. The identified problems were poor technology infrastructure, universities, lecturers, and student disadvantage background. Another study by Kamal et al. (2020) showed that technical challenges (software and hardware) were the common challenges encountered by students during online education. Many students also were not comfortable doing exams online because of the potential of biased and unjust actions such as cheating. Lamb et al. (2020) identified five issues that disadvantaged schools encounter in-home learning: material divide, digital divide, skills and dispositions divide, parental support divide, and adjustments divide. With the high level of poverty and inequality in South Africa, all the five points identified are relevant to the South Africa education system.

Today, more than half (51\%) South African youth aged $18-24$ claims they have no money to pay their tuition according to Stats SA, and more than half (55\%) South African household are poor (Ashley-Cooper et al. 2019; Walker, 2020), where affording life's basics are hard. In addition to the fact that parents of students enrolled in disadvantaged universities may not have the required experiences or skills to support their children in online learning, students from these universities have access to fewer resources, journal databases, the internet, and other infrastructures and services. The pandemic has shown that technology is not a luxury anymore but a crucial part of the education sector (Jantjies, 2020). When addressing this, different factors must be considered, such as the socio-economic challenges faced by lecturers, students, and universities, affordability, staff training, and access to computers and necessary software.

The digital divide issue has been luring in South Africa, particularly the various challenges the societies face from harnessing the full benefits that ICTs can deliver. It is undisputed that an increase in access to enabling technologies has great potential to close the disparities between social groups. The digital divide is a manifestation of poverty, marginalisation, and inequality. The divide is further exacerbated by several issues ranging from unemployment, socio-cultural norms in some societies, lack of proper digital skill training programmes, and depriving rural communities of equal access to digital services. Closing the digital divide gap and making access to technologies equitable, favourable outcomes are inevitable as digitally connected living has potential implications for poverty alleviation, improved education, social well-being, and health (Agbele et al., 2015). It is important to note that digital skills provide a platform and act as catalysts to alleviate poverty (Urvashi et al., 2017).

According to Urvashi et al. (2017), the digital divide is centred on two crucial problems. The first is that the poorer the community, the more limited the digital technology opportunities they are exposed to. This results from a general shortage and high cost of infrastructures ranging from the insufficient power supply to the limited ICT facilities available for use. The second is limited access to digital technology training, resulting in poor digital skills attainment. Hence, leading to individuals and communities not understanding what they can achieve if they possess these skills. It is important to note that the word "digital-divide" has gone beyond just access to network and technology infrastructures. Issues such as social inclusion and digital skills, and competency makes the digital divide a multi-pronged issue (Pather \& Booi, 2020).

The hard effect of the pandemic and policies to contain the virus was that educational activities were replanned to be switched to online platforms for all contact universities in South Africa. Hence, all stakeholders need access to online platforms and resources to support the delivery of learning resources and other activities. However, the immediate transition to the online platforms was a challenge even for big institutions worldwide because they are predominantly used to contact teaching and on-campus activities. It should be noted that the transition was not easy, especially in Africa, where mobile internet adoption at the end of 2019 was still standing at $26 \%$. In the South Africa context, only about $1.7 \%$ of rural households across the country, $0.6 \%$ in Limpopo and $0.8 \%$ in North West had access to the internet as of 2018, while at least $17.3 \%$ of households in urban areas and cities had access to the internet at home. Most of the users of ICT infrastructures in these rural communities are also not advanced users; they use phones basically for voice calls, SMS and social media. With all this data, there is a severe digital gap in all areas of society regarding access and use. Today, most universities expect their students to access and use ICTs to engage in their studies. However, most students, especially those from disadvantaged communities enrolled in disadvantaged 
schools, face affordability problems, or some who enter universities with little or no experience and skills using ICTs will find it difficult to succeed (Pather \& Booi, 2020).

Notwithstanding the complex effect of the pandemic on higher education in South Africa, not all universities were seriously affected. Some were more at risk of not knowing the decision to take during the switch from face-to-face classes to online classes, i.e., they were more vulnerable. For example, universities in urban with several infrastructures and more students residing in cities will be at an advantage over rural universities, with most of their students living in rural communities with little or no access to the internet and other needed devices to excel during online education. For instance, the University of Johannesburg, one of the most prominent urban universities, responded swiftly by providing 5,900 devices to students. They also made 30GB (10GB anytime and 20GB night data) internet data available for students and staff every month (Motala \& Menon, 2020). As stated earlier, no rural university indicated immediate interest to switch to online classes when the universities executives met in April 2020; this indicates a lack of readiness by these disadvantaged universities.

According to Omodan (2020), the inability of disadvantaged universities to respond well to the effect of the pandemic on higher education may be seen as a lack of professional and managerial skills in managing emergencies within the university system. Another study conducted among two rural universities in the Eastern Cape province showed that access to online education resources and platforms is challenging for students and staff, leading to gross inequalities in educational outcomes for learners from different demography.

\section{Method}

The current study presents the readiness of historically disadvantaged higher education institutions in South Africa to adopt online education during the pandemic. The readiness discussed in this paper is solely based on the feedback from lecturers and the administrative initiatives undertaken by the selected institutions. To address this, we conducted a quantitative survey that used a questionnaire to obtain data. Online questionnaires were developed based on the Technology Readiness Adoption Model (TRAM). TRAM is an instrument used to measure people's readiness to use new technologies., i.e., it determines the behaviour of people to use the latest technology based on two dimensions, namely, enablers and inhibitors (Kaushik \& Agrawal, 2021). These two dimensions are further divided into four correlated factors, i.e., innovativeness, optimism, discomfort and insecurity. In this study, online questionnaires were distributed to lecturers in rural universities in May 2020. A five-point Likert Scale with strongly disagree, disagree; neutral; agree, and strongly agree was used to solicit opinions from the respondents. We shared the questionnaire on several WhatsApp groups and did several follow-ups in order to get many respondents.

Additionally, observations were also considered. The authors observed and presented a summary of the events during the lockdown, mainly from the selected institution. During the survey, ethical considerations were observed, and respondents were notified that the study was not related to any contracts they had with the institution.

The composition of the respondents is shown in Table 1. A pilot study including 15 academics was undertaken. This study only targets lecturers who have used and are using the Blackboard learning platform popularly known as WiSeUp at the selected HEI. It is important to note that some lecturers and students walk long distances to access the internet during the pandemic because there is no internet access in their villages and townships. Therefore, people in this category may not be able to participate in the survey. The data was collected when the institutions were on lockdown, so only those with access to the internet participated. Thus, a total of 101 lecturers responded to the questionnaire. Sixty of the respondents $(61 \%)$ were male lecturers, whilst $39(39 \%)$ were female. Two respondents neither indicated their gender nor their age. The modal age class was 30 to 40 years, whilst almost half of the respondents were below 40 . The majority of the respondents were aged between 30 and 50 years, which comprised about $70 \%$ of respondents who indicated their age.

Table 1. Composition of respondents

\begin{tabular}{lllll}
\hline Age & Female & Male & Prefer not to say & Total \\
\hline 30 years or less & 1 & 6 & & 7 \\
Between 30 and 40 years & 15 & 27 & & 42 \\
Between 40 and 50 years & 14 & 13 & & 27 \\
Between 50 and 60 years & 8 & 6 & & 14 \\
60 years or above & 1 & 8 & & 9 \\
Not indicated & & & 2 & 2 \\
Total & 39 & 60 & 2 & 101 \\
\hline
\end{tabular}


The study focuses on feedback regarding lecturers' innovativeness, optimism, discomfort and insecurity while using online education (WiSe Up). The variables were represented as follows: Innovativeness was represented as INNO; optimism was represented as OPT; discomfort as DIS and insecurity was represented as INS. The questionnaire contained many questions. However, this study focuses on the selected variables, which are summarised in Table 2.

Table 2. TRAM selected variables

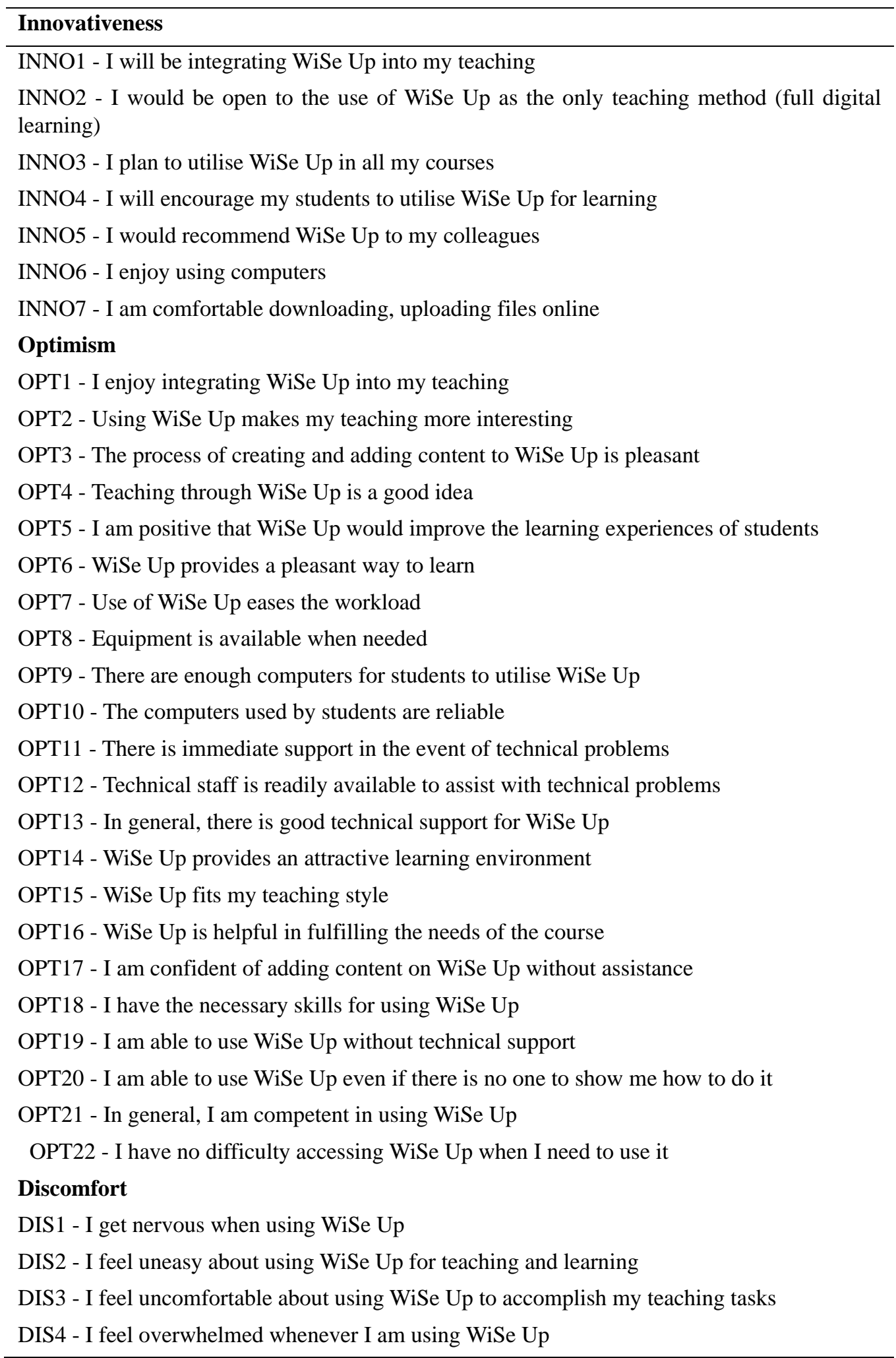




\section{Insecurity}

INS1 - I would need a WiSe Up refresher course

INS2 - I am unhappy with the support service

INS3 - I need refresher training on a regular basis

INS4 - WiSe Up increases my workload

INS5 - There is an intermittent loss of connection whilst using WiSe Up

\subsection{Average Readiness}

The average of the key constructs to determine the technology readiness was summarised based on other research on the readiness level calculation. Conclusions were based on a scale from 1 to 5 . As shown in Table 3, the average close to 1 shows a very low level of readiness. The closer the average is to 5, the higher the level of readiness. Four constructs, i.e., OPT, INNO, DIS and INS, were considered, and the average was calculated. The items considered for calculating the average were those with high factor loadings. The ones with a low factor loading were not considered for average calculation. We also calculated the overall average for the innovators and inhibitors to determine the overall readiness of the respondents.

Table 3. Readiness mean calculation

\begin{tabular}{|c|c|c|c|}
\hline Constructs & Items considered for Average readiness Calculation & Mean & Description \\
\hline OPT & $\begin{array}{l}\text { 1. Using WiSe Up makes my teaching more interesting, } \\
\text { 2. Teaching through WiSe Up is a good idea } \\
\text { 3. I am optimistic that WiSe Up would improve the } \\
\text { learning experiences of students } \\
\text { 4.WiSe Up provides a pleasant way to learn }\end{array}$ & 3.60 & $\begin{array}{l}\text { Since the average is above } 2.5 \text {, } \\
\text { respondents are moderately } \\
\text { optimistic }\end{array}$ \\
\hline INNO & $\begin{array}{l}\text { 1. I would be open to the use of WiSe Up as the only } \\
\text { teaching method } \\
\text { 2. I plan to utilise WiSe Up in all my courses } \\
\text { 3. I will encourage my students to utilise WiSe Up for } \\
\text { learning } \\
\text { 4. WiSe Up provides a pleasant way to learn }\end{array}$ & 3.90 & $\begin{array}{l}\text { Since the average is above } 2.5 \text {, } \\
\text { respondents are moderately } \\
\text { more innovative. }\end{array}$ \\
\hline DIS & $\begin{array}{l}\text { 1. I get nervous when using WiSe Up } \\
\text { 2. I feel uneasy about using WiSe Up for teaching and } \\
\text { learning } \\
\text { 3. I feel uncomfortable about using WiSe Up to } \\
\text { accomplish my teaching tasks }\end{array}$ & 2.19 & $\begin{array}{l}\text { The average is less than } 2.5 \text {; } \\
\text { hence the respondents have a } \\
\text { relatively low discomfort. }\end{array}$ \\
\hline INS & $\begin{array}{l}\text { 1. I would need a WiSe Up refresher course } \\
\text { 2. I am unhappy with the support service }\end{array}$ & 2.91 & $\begin{array}{l}\text { The average is higher than } 2.5 \text {, } \\
\text { implying respondents feel } \\
\text { insecure towards learning } \\
\text { management systems (LMS). }\end{array}$ \\
\hline Motivators & $\begin{array}{l}\text { Considered the items under innovativeness and } \\
\text { optimism }\end{array}$ & 3.8 & $\begin{array}{l}\text { The average is slightly below } \\
\text { 4, which shows a relatively } \\
\text { high level of readiness }\end{array}$ \\
\hline Inhibitors & Considered the items under Discomfort and Insecurity & 2.5 & $\begin{array}{l}\text { This is exactly at } 2.5 \text {, } \\
\text { implying a moderate level of } \\
\text { readiness to adopt. } \\
\text { Respondents have some form } \\
\text { of hesitancy to adopt LMS. }\end{array}$ \\
\hline
\end{tabular}




\subsection{Results from Observations}

Governments and HEIs have put in several efforts in the form of training, affordable and access to the internet for free to assist lecturers and students during online teaching and learning. The following were the efforts observed from the management of the selected HEIs to support online education:

- Many meetings were held to plan for online teaching.

- The LMS training and technology Champions were selected from different faculties.

- Staff and some students received laptops and data.

- Engagements with South African mobile operators to have zero-rated access.

- Both staff and some students, especially first years, received online training.

- The migration to Microsoft Office 365.

- Platforms such as WhatsApp, Zoom, Jitsi and Google classroom were also encouraged to reach students.

- More instructors were loading content online.

The summary of observations is considered to support the overall readiness in the discussion section that follows.

\section{Discussion of Findings}

Considering the definition of innovativeness that included "a willingness to be a technology initiator", we could identify many respondents willing to take up and initiate online learning. Besides the findings from the online questionnaire, many lecturers, through observations, have volunteered to assist, train and showed interest in ensuring that the institution under study continues with the teaching and learning. The average of 3.9, which is very close to 4, indicates a willingness by respondents to use technology for teaching and learning. The considered items under this construct and the responses received clearly show that several respondents are self-motivated and ready to use the available technologies. However, due to the administrative rights, as pointed in the observation section, even though some lecturers can be innovative and modify the LMS, only the teaching and learning administrators have the privilege to do so. Innovativeness has, however, a significant positive influence on perceived usefulness.

It was evident that there was a below-average discomfort where respondents think of technology as overwhelming". The average, which was below 2.5 , shows a low discomfort, and generally, the respondents do not fear LMS use. The fact that the level of discomfort is 2.2 implies some form of discomfort among respondents. The discomfort has a negative influence on perceived ease of use.

Insecurity was above average, indicating some form of insecurity among the respondents. This is explained as a lack of trust in technology and not being sure it will work properly. From the findings, an average of 2.9 on this construct was recorded. The institutions under study have very few technical LMS support teams making it difficult to respond to the issues quickly. As earlier pointed, the lecturers do not have administrative rights and rely on the technical support team for changes on the LMS. This finding is somehow expected as supported by Lee (2001), who points that technology adoption is a process and requires effort and planning. There is a need to have appropriate skills, and there is still a considerable gap between the developed HEIs and the less developed ones.

Our findings are similar, though, in the technologies in education and general technology readiness in mobile commerce to those of Jin (2020). According to Jin (2020), some aspects of the TRAM are more linked and essential to the satisfaction and behavioural intention to use the technology. This was similar to what we found, where the intention to use LMS and other technologies in teaching and learning is enabled by the perceived ease of use and perceived usefulness. On the other hand, teaching and learning adoption by more users and for further use is enabled by the satisfaction of the technology. Similar to Jin (2020) findings, this study shows that technology readiness will positively influence perceived ease of use and usefulness. We could deduce that the innovative lecturers find that the ease and usefulness of LMS are common. On the other hand, those lecturers who are more insure and have some form of discomfort will have different views of perceived usefulness.

Furthermore, in most cases, studies include users who may be not familiar with the technologies or have been introduced to the technology. In our study, the focus was on only those already using and familiar with the LMS. The results were similar to other studies, only different on the degree of level, such as the study in Lee (2001). The difference in this study results is mainly the average level of each construct; of course, the overall conclusion remains the same on the effects on motivators and inhibitors to the technology adoption. 


\section{Conclusion}

Public universities across the country have adopted online education to overcome the current lockdown policies that do not encourage a large gathering, making face-to-face learning impossible. However, it is essential to note that online education is beyond the reach of some students and even lecturers unless interventions happen at several stages. This study focuses on historically disadvantaged HEIs lecturers' readiness to adopt online education platforms during the pandemic. Based on the feedback from lecturers, this study showed that many respondents were not comfortable using the available learning platforms. They do not fully trust the system, i.e., some feel the system will not work correctly or serve its purpose.

Despite having many staff motivated to adopt technology, the HEI still has more work to accommodate all students and lecturers. The paper is limited to the findings and observations made by the authors. However, there are many lessons learnt that the provincial and national governments could learn to improve on. The HEI involved has key lessons to learn, some that are institutional while others are external as they are infrastructural related and affects the adoption of technology by lecturers. For example, a lack of basic computer skills by lecturers will hinder the adoption of online teaching. Another major challenge lecturers and students of these HEIs face is the unavailability of internet networks in rural areas. As explained earlier, some had to walk a long distance to access their emails, social media and other internet-based platforms to enhance online teaching and learning. The affordability of technology-enabled devices is a common issue. Many complained of the high cost of internet bundles, modems and laptops. All these challenges combined make it difficult for HEIs in rural areas to switch to online education immediately after the lockdown was announced.

\section{References}

Agbele, K. K., Oriogun, P. K., Seluwa, A. G., \& Aruleba, K. D. (2015, November). Towards a model for enhancing ICT4 development and information security in healthcare system. In 2015 IEEE International Symposium on Technology and Society (ISTAS) (pp. 1-6). IEEE. https://doi.org/10.1109/ISTAS.2015.7439404

Ashley-Cooper, M., van Niekerk, L. J., \& Atmore, E. (2019). Early childhood development in South Africa: Inequality and opportunity. South African schooling: The enigma of inequality, 87-108. https://doi.org/10.1007/978-3-030-18811-5_5

Baran, E., Correia, A. P., \& Thompson, A. (2013). Tracing successful online teaching in higher education: Voices of exemplary online teachers. Teachers College Record, 115(3), 1-41.

Barnard, J. (1997). The World Wide Web and higher education: The promise of virtual universities and online libraries. Educational technology, 37(3), 30-35.

Bates, A. T. (2005). Technology, e-learning and distance education. Routledge. https://doi.org/10.4324/9780203463772

Ebner, C., \& Gegenfurtner, A. (2019, September). Learning and satisfaction in webinar, online, and face-to-face instruction: a meta-analysis. In Frontiers in Education (Vol. 4, p. 92). Frontiers. https://doi.org/10.3389/feduc.2019.00092

Gegenfurtner, A., Zitt, A., \& Ebner, C. (2020). Evaluating webinar-based training: a mixed methods study of trainee reactions toward digital web conferencing. International Journal of Training and Development, 24(1), 5-21. https://doi.org/10.1111/ijtd.12167

Graham, A. (2019). Benefits of online teaching for face-to-face teaching at historically black colleges and universities. Online Learning, 23(1), 144-163. https://doi.org/10.24059/olj.v23i1.1435

Hijazi, S. (2003). Interactive technology impact on quality distance education. Electronic Journal of E-learning, 1(1), $35-44$.

Howard, S. K., Tondeur, J., Siddiq, F., \& Scherer, R. (2021). Ready, set, go! Profiling teachers' readiness for online teaching in secondary education. Technology, Pedagogy and Education, 30(1), 141-158. https://doi.org/10.1080/1475939X.2020.1839543

Jaggars, S., \& Bailey, T. R. (2010). Effectiveness of fully online courses for college students: Response to a Department of Education meta-analysis.

Jantjies, M. (2020). How South Africa can address digital inequalities in e-learning. The Conversation. $\mathrm{http}: / /$ theconversation. Com

Jin, C. H. (2020) Predicting the Use of Brand Application Based on a TRAM, International Journal of 
Human-Computer Interaction, 36(2), 156-171. https://doi.org/10.1080/10447318.2019.1609227

Joshi, P., Thukral, A., Joshi, M., Deorari, A. K., \& Vatsa, M. (2013). Comparing the Effectiveness of Webinars and Participatory learning on essential newborn care (ENBC) in the class room in terms of acquisition of knowledge and skills of student nurses: a randomised controlled trial. The Indian Journal of Pediatrics, 80(2), 168-170. https://doi.org/10.1007/s12098-012-0742-8

Kamal, A. A., Shaipullah, N. M., Truna, L., Sabri, M., \& Junaini, S. N. (2020). Transitioning to online learning during COVID-19 Pandemic: Case study of a Pre-University Centre in Malaysia. International Journal of Advanced Computer Science and Applications, 11(6). https://doi.org/10.14569/IJACSA.2020.0110628

Kaushik, M. K., \& Agrawal, D. (2021). Influence of technology readiness in adoption of e-learning. International Journal of Educational Management. https://doi.org/10.1108/IJEM-04-2020-0216

Lamb, S., Maire, Q., Doecke, E., Macklin, S., Noble, K., \& Pilcher, S. (2020). Impact of learning from home on educational outcomes for disadvantaged children: Brief assessment.

Lee, J. H. (2001). Education for Technology Readiness: Prospects for Developing Countries. Journal of Human Development, 2(1). https://doi.org/10.1080/14649880120050

Lim, D. H., Morris, M. L., \& Kupritz, V. W. (2007). Online vs. blended learning: Differences in instructional outcomes and learner satisfaction. Journal of Asynchronous Learning Networks, 11(2), 27-42. https://doi.org/10.24059/olj.v11i2.1725

Motala, S., \& Menon, K. (2020). In search of the'new normal': reflections on teaching and learning during Covid-19 in a South African university. Southern African Review of Education with Education with Production, 26(1), 80-99.

Muilenburg, L. Y., \& Berge, Z. L. (2005). Student barriers to online learning: A factor analytic study. Distance education, 26(1), 29-48. https://doi.org/10.1080/01587910500081269

Navarro, P., \& Shoemaker, J. (2000). Performance and perceptions of distance learners in cyberspace. American journal of distance education, 14(2), 15-35. https://doi.org/10.1080/08923640009527052

Omodan, B. I. (2020). The Vindication of Decoloniality and the Reality of COVID-19 as an Emergency of Unknown in Rural Universities. International Journal of Sociology of Education, 1-26. https://doi.org/10.17583/rise.2020.5495

Pather, S., \& Booi, E. (2020, November). An assessment of student resource readiness for online learning during COVID 19: A South African case study. In Proceedings of ICERI2020 Conference, 9(10), 21125. https://doi.org/10.21125/iceri.2020.2186

Pulham, E., \& Graham, C. R. (2018). Comparing K-12 online and blended teaching competencies: A literature review. Distance Education, 39(3), 411-432. https://doi.org/10.1080/01587919.2018.1476840

Sharon Dell. (2020). Universities prepare for online teaching and learning. [online] University World News. Available at: https://www.universityworldnews.com/post.php?story=20200417150627516 [Accessed 20 August 2021]

Siedner, M. J., Kraemer, J. D., Meyer, M. J., Harling, G., Mngomezulu, T., Gabela, P., ... \& Herbst, K. (2020). Access to primary healthcare during lockdown measures for COVID-19 in rural South Africa: an interrupted time series analysis. BMJ open, 10(10), e043763. https://doi.org/10.1136/bmjopen-2020-043763

Sussman, S., \& Dutter, L. (2010). Comparing student learning outcomes in face-to-face and online course delivery. Online Journal of Distance Learning Administration, 13(4), 6-11.

Urvashi, A., Chetty, K., Gcora, N., Josie, J., \& Mishra, V. (2017). Bridging the Digital Divide: Skills for The New Age. Policy Brief, G20 Insights. 05.04. 2017. https://doi.org/10.5018/economics-ejournal.ja.2018-24

Walker, M. (2020). The well-being of South African university students from low-income households. Oxford Development Studies, 48(1), 56-69. https://doi.org/10.1080/13600818.2019.1672143

\section{Copyrights}

Copyright for this article is retained by the author(s), with first publication rights granted to the journal.

This is an open-access article distributed under the terms and conditions of the Creative Commons Attribution license (http://creativecommons.org/licenses/by/4.0/). 